\title{
Identification of risk factors related to the production and use of alternative fuels
}

ABSTRACT: The article analyzes the risk factors related to the energy use of alternative fuels from waste. The essence of risk and its impact on economic activity in the area of waste management were discussed. Then, a risk assessment, on the example of waste fractions used for the production of alternative fuel, was carried out. In addition, the benefits for the society and the environment from the processing of alternative fuels for energy purposes, including, among others: reducing the cost of waste disposal, limiting the negative impact on water, soil and air, reducing the amount of waste deposited, acquisition of land; reduction of the greenhouse effect, facilitating the recycling of other fractions, recovery of electricity and heat, and saving conventional energy carriers, were determined.

The analysis of risk factors is carried out separately for plants processing waste for alternative fuel production and plants producing energy from this type of fuel. Waste processing plants should pay attention to investment, market (price, interest rate, and currency), business climate, political, and legal risks, as well as weather, seasonal, logistic, technological, and loss of profitability or bankruptcy risks. Similar risks are observed in the case of energy companies, as they operate in the same external environment. Moreover, internal risks may be similar; however, the specific nature of the operation of each enterprise should be taken into account.

Energy companies should pay particular attention to the various types of costs that may threaten the stability of operation, especially in the case of regulated energy prices. The risk associated with the inadequate quality of the supplied and stored fuels is important. This risk may disrupt the technological process and reduce the plant's operational efficiency. Heating plants and combined heat and

\footnotetext{
${ }^{1}$ Cracow University of Technology, Kraków, ORCID: 0000-0002-0695-8864.

2 AGH University od Science and Technology, Kraków, ORCID: 0000-0002-2256-4654.

${ }^{3}$ AGH University od Science and Technology, Kraków, ORCID: 0000-0002-7816-115X, e-mail: niwaszcz@zarz. agh.edu.pl
} 
power plants should also not underestimate the non-catastrophic weather risk, which may lead to a decrease in heat demand and a reduction in business revenues.

A comprehensive approach to risk should protect enterprises against possible losses due to various types of threats, including both external and internal threats.

KEYWORDS: waste, energy recovery, alternative fuels, risk, combined heat and power plants, heating plants, electricity and heat

\section{Introduction}

Any type of business is associated with exposure to certain risks. Risk analysis has been discussed broadly in many scientific papers. According to the Multimedia Encyclopedia of PWN, the risk is the probability of failure and loss. A debatable and uncertain operation (Multimedia Encyclopedia of PWN, 2003). In turn, according to K. Jajuga (1998) risk is the lower than expected income return (...) (Jajuga 1998).

In the literature on the subject there are numerous definitions of this concept. According to ISO/IEC 73 (International Organization for Standardization, ISO) risk is the combination of the probability of an event and its consequence.

Regardless of the type of undertaking, the possibility of unplanned events resulting from many factors always exists. They may entail both positive (thus creating an opportunity to achieve additional benefits) and negative effects (identified as a threat to the implementation of the planned goals). In light of the above, one can speak about a neutral approach to risk management. However, both scientists and practitioners focus their attention on the adverse consequences of individual events in order to protect themselves from their effects (i.e. to eliminate or at least limit them).

Risk analysis methods are a key element in the analysis of this concept. Logically, one cannot come up with a remedy to a problem without knowing its cause. Similarly, we will not be able to develop effective risk mitigation tools without knowing the factors that influenced its formation. Risk factors are conditions that affect the likelihood of loss or gain and their size (Williams et al. 2002). Entrepreneurs, employees, and managers performing many different business activities are not sure whether they will achieve their goals. If you manage to achieve them, the risk is not a significant problem. Otherwise the situation becomes more complicated. It can therefore be stated that attaining the goal is possible but not necessarily certain. The common sources of risk are the lack of data and insufficient data (Holton 2004). The reason may be the lack of competence of decision-makers. It can also be the result of changes occurring both inside the tested system and in its environment. Therefore, the risk has two basic characteristics: it is a negative deviation of results from the assumed goal; it involves a decision-making process that pertains to the future.

The factors related to the specific profile of economic activity and the sector have a considerable impact on the level of risk. In the group of "sectoral" factors, particular attention should be paid to the structure of the sector and the strength of the competition. Internal factors include 
micro-economic factors closely related to a specific company. Because each company sets individual goals (tactical, operational, and strategic), risk-generating factors can be considered, taking the organizational structure of the company at the production, logistics, marketing, and administration levels into account (Iwaszczuk et al. 2013). In turn, in a broader sense, the risk should be defined as a meso, macro or megaeconomic risk, which is more important from the point of view of entities involved in economic processes. Therefore, risk factors can be divided into two groups: of external and internal origin.

External factors include such risks as: fluctuations in the prices of goods, raw materials (more: Winkler-Drews 2009; Do 2014) and services, sectoral changes, demand volumes, customer preferences, the income of potential buyers, suppliers, and competitors, fluctuations in the business cycle and its impact on buyers and producers, the availability of loans, investment risk (more: Jajuga 2009a), currency risk, and interest rate risk (more: Szczepański and Szyszko 2007; Soin and Collier 2013).

On the other hand, internal factors include: the risks related to disruptions in cash flows, reduced financial liquidity as a result of the imbalance of financial flows (more: Borys 1996), and a decrease in Intellectual capital. Furthermore, the source of internal risk might come from a wrongly selected management team, disruptions in supplies of the finished product, inadequate qualifications of employees, equipment and information systems failure, disruptions in basic and additional production processes, organizational problems after changes in the company structure (e.g. as a result of merger, integration, or acquisition), errors in planning and accounting, and the risk of bankruptcy.

In fact, the external risk triggers processes that generate internal risks. That is why it is so important to recognize them in advance to develop different strategies for protection against a particular type of risk, depending on the changes taking place in the external environment.

The purpose of this article is to identify risks for refuse-derived fuel plants and for plants producing electricity and heat using this type of fuel.

\section{Waste as a source of electricity and heat}

Due to the dynamic development and globalization of the global economy, huge amounts of both accumulated and newly generated waste are becoming an increasingly big problem for all countries. Currently, it is one of the most important civilization problems. The governments of many countries and international organizations are therefore taking legal steps to reduce the amount of waste generated and their development. As a result of legal regulations regarding waste management, entities operating in this segment of the economy are obliged to reduce waste storage in favor of other forms of their management. The hierarchy of waste management methods is of great importance, as it allows for reducing the negative impact of waste on the environment and human health, as well as the optimal use of materials contained in waste. 
The Act of 14 December 2012 on Waste - uniform text (following the provisions of Directive 2008/98/EC on waste) introduces the following hierarchy of waste management methods:

1) waste prevention;

2) preparation for re-use;

3) recycling;

4) other recovery processes, e.g. energy recovery, production of alternative fuels;

5) disposal.

Recovery is the penultimate recommended method of waste management and should be used in the case of non-recyclable waste. One of the effective recovery methods is to use the combustible fraction of waste as a fuel in high temperature combustion processes, e.g. for energy purposes. Also, low-temperature waste treatment technologies are used to obtain gas hydrocarbons, which can then be processed in peripheral devices for electricity and heat.

Energy recovery from waste can be carried out both in dedicated installations and in installations implementing other industrial processes, such as, for example: power boilers, clinker kilns, brick kilns, lime kilns, blast furnaces, furnaces used in metallurgy, coke batteries, or Dutch ovens (Wasielewski and Bałazińska 2018; EC-DGE 2003; Hilber et al. 2007; Sobolewski et al. 2007).

The Regulation of the Minister of Economy of 16 July 2015 on the depositing of wastes in landfills (Journal of Laws of 2015, item 1277) introduced criteria for the storage of waste. According to this regulation, municipal waste collected and waste resulting from the treatment of municipal waste cannot be stored in landfills for waste other than hazardous and inert waste if their net calorific value is higher than $6 \mathrm{MJ} / \mathrm{kg}$. However, these wastes can be recovered, e.g. in the process of thermal transformation. Waste fractions for recovery can come from selective collection art households ("at source") or can be separated in mechanical and biological waste treatment plants (MBP) (Klojzy-Karczmarczyk et al. 2015).

The quantitative potential of fuels generated from mixed municipal waste in Poland, depending on the source, ranges from 4.5 to even 6 million Mg per year. Currently, the main consumers of these fuels are cement plants. However, their ability to use the available alternative fuels is insufficient. The involvement of the power sector and heating sector could stimulate the developed thermal waste processing system (Krawczyk and Szczygieł 2013).

In order to use waste for energy generation, it must be subjected to proper segregation and treatment. The resulting flammable waste is referred to as alternative fuels and RDF (Refused Derived Fuel). It should be noted that the term alternative fuel is commonly used to describe combustible, shredded waste with a homogeneous mixing ratio, constituting a mixture of non -hazardous waste with or without solid fuel, liquid, or biomass (Wasielewski and Bałazińska 2018). The following groups of municipal and industrial waste are the most useful for the production of alternative fuels:

1. Plastics. These are mainly defective plastic products, packaging films, and packaging from polypropylene, polyethylene, polystyrene, and others.

2. Textiles, including textile cord (recycling of tires, linings and upholstery from the automotive industry, etc.), are usually polyesters and other types of plastics mixed with fabrics of natural origin. 
3. Rubber coming from damping elements and from the automotive industry, casings of metal elements or cables, etc.

4. Wood includes, among others, sawdust, furniture waste, wood chips from food processes, energy willow, and Chinese grass - Miscanthus.

5. Cellulose, mainly waste from recycled paper.

6. Waste mixtures (Walendziewski et al. 2017).

Klojzy-Karczmarczyk and Staszczak (2017) have shown that energy fractions occupy a significant share of the stream of the generated municipal waste, particularly in urban areas. Such fractions were initially considered to have a calorific value higher than $6 \mathrm{MJ} / \mathrm{kg}$, which was related to the ban on their storage. It has been shown that plastic waste, paper and cardboard waste, textile waste, wood waste and multi-material waste can be successfully considered as energy fractions, because their net calorific value is even higher than $12 \mathrm{MJ} / \mathrm{kg}$, which is the minimum value for fuels. The largest share (up to 39\%) of energy fractions is observed in wastes generated by residents of large cities, slightly lower (29\%) in wastes produced by residents of small towns, while the lowest (22\%) in wastes generated by rural residents (Klojzy-Karczmarczyk and Staszczak 2017).

In order to become a source of heat and electricity, combustible waste fractions must be processed in mechanical and biological waste treatment plants or similar units. Then they can be an alternative (or rather complement) to conventional fuels, because their price would be much lower.

In addition to the lower price, the use of waste for energy recovery can bring a number of other benefits - not only for the economy, but also for the ecosystem. The main benefits include:

$\checkmark$ reducing the negative impact on water (ground and underground water);

$\downarrow$ clean soil and, as a result, better products of agricultural origin;

$\checkmark$ reduction of air pollution;

$\checkmark$ reduction of the greenhouse effect;

$\checkmark$ recovery of electricity and heat;

$\checkmark$ recycling of other fractions derived from waste;

$\checkmark$ reducing the amount of waste deposited in landfills;

$\downarrow$ increasing areas of vacant land;

$\downarrow$ reduction of waste disposal costs;

$\checkmark$ saving primary energy carriers.

Despite the obvious advantages, the production and use of alternative fuels for energy purposes (like any other economic activity) is also associated with a number of dangers, referred to as risks. In order to identify risk factors, these two activities will be considered separately. 


\section{Risk factors in refuse-derived fuel plants}

To start a business, one must first invest. The main investment risk factor is uncertainty regarding the profitability of the investment. For this reason, it is difficult to find private investors interested in the given industry, especially in the absence of support from local and central authorities. The solution may be the arrangement between public and private sectors, e.g. a public-private partnership. State subsidies for such activities are possible if central and/or local authorities consider this to be appropriate.

The investment risk is closely related to interest rate risk (when financing investments with loans) and currency risk (if foreign investors' funds are invested or if they take out a loan or a bond loan in a foreign currency). An increase in the interest rate, as well as an increase in the exchange rate of a foreign currency, may lead to an increase in costs and, as a consequence, affect the profitability of the entire project.

In turn, the market risk is associated with price increases (price risk). Refuse-derived fuel plants start the production process from collecting municipal and industrial waste. The transport of the raw material, weighing, unloading, loading and other activities take place with the use of company cars. The delivery of finished products (alternative fuels, recovered metals, and others) to heating plants, combined heat and power plants, and recycling plants is also carried out with the use of road transport. Therefore, its cost must have a large share in the total cost of production, and its increase will reduce the competitiveness of the plant. Similarly, the increase in electricity prices will increase the operating costs and the prices of the products received. This is due to the fact that electricity is used in various activities of waste processing plants, including: grinding, compacting, pressing, cleaning, packing, dedusting, filtration of odors, drying of waste, sieving, sorting, etc.

Due to the increase in operating costs, the profitability of the plant may decrease. This will happen if the increase in costs is not covered in part or in whole by an increase in fees for accepting waste or an increase in the price of alternative fuels produced (although at the moment it is unlikely). A similar threat is associated with a drop in prices on the market of alternative fuels, e.g. when prices do not cover the production costs. As a consequence, the plant will face not only a temporary loss of liquidity, but also bankruptcy.

Business partners can also contribute to the emergence of threats. One of the examples of their negative impact are disruptions in the supply of waste, jeopardizing the stability of the plant's operation. They may be caused by an uneven supply of raw material, which is very sensitive to both seasonal changes and the variability of weather conditions. This is confirmed by the increased volume of PET bottles in the summer period, while in the winter months a significant reduction of this fraction in municipal waste (as a result of a decrease in the consumption of soft drinks) can be observed.

Therefore, weather risk (both non-catastrophic and catastrophic) as well as climate change may also have a negative impact on the operations of the production facilities discussed. The non-catastrophic weather risk is associated, for example, with excessively low air temperature, 
required to dry waste or, for example, with high humidity --due to low temperature, rain, snow, etc. In turn, catastrophic weather risk (such as floods, landslides, hurricanes, or whirlwinds) can lead to damage to installations, dampness of warehouses with raw materials and finished products, etc. Waste processing plants are also struggling with logistical problems related to weather risks, e.g. due to high snowfall, black ice, floods, landslides, hurricanes, or whirlwinds. The causes of supply chain disruptions can be on both the suppliers and the consumers side.

The political and legal risks affect all entities operating in a given sector of the economy (Jajuga 2009b). Waste treatment plants are also exposed to its impact. It is based on constant changes in the regulations and legal norms that may disturb the stability of the plant's operation due to changes or the introduction of additional requirements, regulations, etc. Adaptation to new requirements may take time, entail additional costs, and even lead to the temporary cessation of production.

Another cyclical risk is cyclical economic development (to be more exact - business cycles). During periods of economic downturn, the supply of waste from which alternative fuels are produced may decrease due to: lower household expenses (for current consumption); reducing the supply of post-production waste from the industry (due to the reduction in production volume); reducing the number of business entities (as a result of their bankruptcy or temporary suspension of operations).

Finally, the lack of acceptance by the local community for a new waste treatment plant, resulting from residents' concerns about: the unpleasant smell and noise from the plant; heavy traffic (noise, road damage); reduced attractiveness of real estate and land. This type of threat is called social risk.

Continuing the discussion, it is worth paying attention to the risk factors closely related to the production process. They are the so-called specific internal risks.

Since the processes associated with the use of alternative fuels require compliance with certain quality criteria, the parameters (calorific value, homogeneity of parameters, chemical composition, maximum size, and homogeneity) of the produced fuel shall comply with all the requirements of the heating plants. This is a rather complicated problem, due to the large heterogeneity and variability of the waste structure over time, from which fuels are produced. Requirements for RDF result from the specificity of the installation, e.g. heating plant, and applicable emission standards. The specificity of the installation is that the chemical composition of co-combusted waste has a significant impact not only on the quality of heat generated, but also on the safety and stability of operation of this and other installations in the heating plant. For this reason, restrictions may apply to the content of: chlorine, fluorine, alkali, heavy metals, and toxic aromatic particles.

In addition, there is a risk associated with the storage of waste, which may deteriorate their quality. Therefore, it is essential to ensure that the supply of raw materials is synchronized with the manufacturing process. If this is not possible, appropriate conditions (temperature, humidity, roofing etc.) should be provided in order to prevent wetting, overheating, rotting etc. However, this entails additional costs (insurance of warehouses, security costs).

What is more, in the case of a finished product, the storage risk must be expected. To ensure the continuity of supplies, it is necessary to store the produced alternative fuels, the quantity of which is difficult to precisely determine. The storage method is also of great importance. Fuel 
must be stored in covered warehouses, in order to be protected protect against moisture, which could negatively affect its net calorific value, increase transport costs and cause numerous procedural problems for heat and power plants, starting from corrosion, through to self-heating of waste during storage, and ending with self-ignition. In such a case, there is a risk of losing the quality and value of the finished product. The consistency of the fuels obtained, which should be easy to dose, is also of great importance. The fuels shall be characterized by good homogeneity and uniformity in the entire mass.

The risks, risk factors and types of risk described above, as well as the possible consequences of their occurrence, are summarized in Table 1.

TABLE 1. Key risk factors in the production of alternative fuels

TABELA 1. Kluczowe czynniki ryzyka przy wytwarzaniu paliw alternatywnych

\begin{tabular}{|c|c|c|}
\hline Risk Factor & Risk type & Threats and related risks \\
\hline $\begin{array}{c}\text { Uncertainty about the profitability of the } \\
\text { investment }\end{array}$ & Investment risk & $\begin{array}{c}\text { Currency risk } \\
\text { Interest rate risk } \\
\text { Business climate risk } \\
\text { Social risk }\end{array}$ \\
\hline $\begin{array}{l}\text { The increase in prices of motor fuels } \\
\text { The increase in electricity prices } \\
\text { Lowering fees for accepting waste } \\
\text { The decrease in alternative fuel prices }\end{array}$ & Price risk & $\begin{array}{l}\text { Increase in production costs } \\
\text { Loss of competitiveness } \\
\text { Reduction in profitability } \\
\text { The risk of bankruptcy }\end{array}$ \\
\hline $\begin{array}{l}\text { Disturbances in the supply of raw } \\
\text { materials }\end{array}$ & Logistic risk & $\begin{array}{l}\text { Seasonal risk } \\
\text { Weather risk }\end{array}$ \\
\hline $\begin{array}{c}\text { Changes in regulations and legal } \\
\text { standards }\end{array}$ & Political and legal risk & $\begin{array}{l}\text { Increase in production costs } \\
\text { Loss of competitiveness } \\
\text { Reduction in profitability } \\
\text { The risk of bankruptcy }\end{array}$ \\
\hline Phase of the business cycle & Business climate risk & $\begin{array}{c}\text { Decrease in demand for a finished } \\
\text { product } \\
\text { Reduction in profitability } \\
\text { The risk of bankruptcy }\end{array}$ \\
\hline No social acceptance & Social risk & Investment risk \\
\hline Raw materials storage method & Storage risk & $\begin{array}{l}\text { Loss of quality } \\
\text { Technological risk }\end{array}$ \\
\hline $\begin{array}{l}\text { The method of storage of finished } \\
\text { products }\end{array}$ & Storage risk & $\begin{array}{l}\text { Loss of quality } \\
\text { Depreciation } \\
\text { Profitability risk }\end{array}$ \\
\hline
\end{tabular}

Source: own work.

The conducted analysis will be beneficial for the managers of waste treatment plants, which will later be used for energy purposes. However, it should be remembered that cooperating entities interact with each other to a greater or lesser extent. There is no doubt, therefore, that threats affecting business partners (e.g. suppliers of alternative waste) are likely to adversely affect 
the operations of a given economic entity - the recipient of alternative fuels (e.g. heating plants or combined heat and power plants). This relationship is also reversed.

\section{Risk factor in plants using alternative fuels}

As already mentioned, the use of municipal waste for energy production has many environmental benefits (reduction of environmental burden of landfilling). In addition, the possibility of energy production in municipal waste treatment plants (reduction of conventional fuels consumption) is another advantage. Taking the climate package and increasingly stringent ecological and energy requirements into account, it can be stated that the developed infrastructure for energy recovery from waste is becoming an important element of the Polish energy policy (Cyranka and Jurczyk 2016).

The combined heat and power plant in Zabrze opened on September 20, 2018 may serve as an example of a plant co-firing alternative fuels. The Zabrze CHP plant is equipped with a multi-fuel cogeneration unit (with a capacity of $220 \mathrm{MW}$ ) using various types of biomass, coal, and alternative fuels (RDF). It provides heat to almost 70,000 households in Zabrze and Bytom (http://www.eczabrze.fortum.pl/o-projekcie/).

However, the co-combustion of alternative fuels obtained from waste requires large investment outlays. Thus, the investment risk will also be crucial in this case. The discussed project involves the construction of new power plants and modernization of the existing heating plants and combined heat and power plants, where alternative fuel will be co-incinerated with conventional fuel and/ or biomass. It is well-known that investing is less dangerous during periods of growing economic activity; when the economy develops, new commercial and service ventures and workplaces are created, and, as a consequence, investment and consumption demand is growing. However, during the recession this type of risk takes on a completely different importance. In times of recession, the demand for heat and electricity is lower (especially from the largest recipients - enterprises and institutions), which is caused by the general economic slowdown. Households try to save energy mainly due to lowering disposable personal income as a result of job loss or reduced earnings.

In the economic calculation of plants using alternative fuels, one should take the possibility of increasing the prices of motor fuels (resulting from fluctuations in the price of crude oil on the world market) and other raw materials into account. This increase will contribute to the increase in the cost of electricity and heat production, which does not always translate into an increase in the price of the final product (especially due to regulated prices in Poland). As a result, the profitability will decrease, which may lead to the company's bankruptcy.

In turn, the impact of climate change and weather risk (more: Preś 2007) is most noticeable in the case of the heating industry. If there are more and more periods with relatively high air temperature during the heating season, the demand for heat decreases - this is a non-catastrophic weather risk. However, various types of weather anomalies and natural disasters (catastrophic weather ha- 
zards) can destroy infrastructure, installations, and fuel supplies. The weather risk also involves logistic risk, manifested by the inability to deliver fuel to the plant. One possible solution is to build additional roofed storage areas and bunkers, where alternative fuel will be stored for many months until the heating season. However, the negative side of such a solution includes the potential threat of self-ignition, wetting, and damping of stored fuels and additional costs for the enterprise.

Another risk factor is the irregular supply (reduction /absence or interruption of supply) of alternative fuels. In the summer, MBP (mechanical and biological waste treatment) plants collect and process much more waste as a potential raw material for alternative fuels, while in the winter a significant reduction in the supply of this fraction of waste can be observed. The uneven heat demand due to seasonality - the so-called seasonal risk is added to this. In the summer months the supply of alternative fuels is greater, but the demand from consumers is much lower (only for heating water). In winter, however, the situation is reversed. Therefore, the question arises, who (the plant producing alternative fuels or the plant using them) should collect and store fuel supplies to ensure the stability of the operation of the heating plant or combined heat and power plant? The continuity of fuel supplies, so that their lack will not cause disruptions in the supply of heat, hot tap water, and electricity for end consumers, is of great importance.

Since it is not possible to predict all circumstances threatening the continuity of supplies, the heating plant must have a minimum fuel reserve. Here, however, the problem of determining its size, which is associated with the freezing of cash and the maintenance of additional waste landfills/bunkers arises. There is also a risk for the fuels themselves - self-ignition, dampness, wetting, etc. Due to the low density of alternative fuels, it may be necessary to increase the storage area (compared to conventional fuels used so far - e.g. coal, whose density is much higher) and, more importantly, to increase the size of the boiler feeder and combustion chamber in order to maintain the normal production process.

Determining the size of the supply batch is of great importance due to the fact that the calorific value of RDF fuel in a particular batch may be lower than assumed (hence the risk of failure to provide the appropriate temperature and /or combustion time), so the plant will need more fuel than expected or would have to change (if possible) the rate of fuel supply to the boiler. The most important criterion is that supplies of waste fuel must enable the continuous operation of the heating plant.

The political and legal risk, as in the previous case, manifests itself in the form of constant changes in regulations, laws, and regulations that may disrupt the plant operation due to changes or additional requirements.

The lack of acceptance from the local community may also affect district heating plants, especially those newly built, if it is known that they will burn waste. Concerns of the local community may include: odor, noise from the plant, heavy traffic of trucks carrying secondary fuels, destruction of local roads that reduce the attractiveness of real estate and land.

One of the more important internal risks is technological risk. This may be related to the possibility of particles penetrating the devices that may damage them. Fuel with a higher (than assumed) content of harmful substances, causing corrosion and erosion in boilers and other equipment, may also be a threat, resulting in deposits on heating surfaces that will deepen the 
corrosive processes. As a consequence, this will affect the amount of heat taken over by individual surfaces (Wasielewski and Tora 2013).

The variability of the net heating value and moisture content in secondary fuels may also negatively affect the course of technological processes. On the other hand, the change in the amount and properties of solid particles carried by exhaust gases as a result of co-firing translates into different levels of exhaust emissions, while fines can be imposed when maximum emission limits are exceeded. In order to avoid them, the company would have to invest in additional filters, which means additional costs. These, in turn, may entail the risk of reducing the profitability of the project and, in consequence, lead to bankruptcy.

Table 2 presents a list of key risk factors along with a brief description and the indication of other related risks.

TABLE 2. Key risk factors when using alternative fuels in heating plants and combined heat and power plants

TABELA 2. Kluczowe czynniki ryzyka przy wykorzystaniu paliw alternatywnych przez ciepłownie i elektrociepłownie

\begin{tabular}{|c|c|c|}
\hline Risk Factor & Risk type & Threats and related risks \\
\hline $\begin{array}{l}\text { Uncertainty about the profitability of } \\
\text { the investment or modernization of the } \\
\text { existing plants. }\end{array}$ & Investment risk & $\begin{array}{c}\text { Currency risk } \\
\text { Interest rate risk } \\
\text { Business climate risk } \\
\text { Social risk }\end{array}$ \\
\hline $\begin{array}{l}\text { The increase in prices of motor fuels } \\
\text { The increase in prices of alternative fuels } \\
\text { A decrease in electricity prices } \\
\text { Decrease in thermal energy prices }\end{array}$ & Price risk & $\begin{array}{l}\text { Increase in production costs } \\
\text { Loss of competitiveness } \\
\text { Reduction in profitability } \\
\text { The risk of bankruptcy }\end{array}$ \\
\hline $\begin{array}{l}\text { Disturbances in the supply of raw } \\
\text { materials }\end{array}$ & Logistic risk & $\begin{array}{c}\text { Seasonal risk } \\
\text { Weather risk } \\
\text { Climate change }\end{array}$ \\
\hline Climate change & Weather risk & $\begin{array}{l}\text { Decrease in heat demand } \\
\text { Decrease in demand for electricity } \\
\text { Reduction in profitability }\end{array}$ \\
\hline Poor quality of raw material & $\begin{array}{l}\text { The risk of raw } \\
\text { material quality }\end{array}$ & $\begin{array}{c}\text { Technological risk } \\
\text { The reduction in boiler efficiency } \\
\text { Reduction in profitability }\end{array}$ \\
\hline Changes in regulations and legal standards & $\begin{array}{l}\text { Political and legal } \\
\text { risk }\end{array}$ & $\begin{array}{l}\text { The risk of increased production costs } \\
\text { Loss of competitiveness } \\
\text { Reduction in profitability } \\
\text { The risk of bankruptcy }\end{array}$ \\
\hline Phase of the business cycle & Business climate risk & $\begin{array}{c}\text { Decrease in demand for a finished product } \\
\text { Reduction in profitability } \\
\text { The risk of bankruptcy }\end{array}$ \\
\hline No social acceptance. & Social risk & Investment risk \\
\hline Alternative fuel storage method. & Storage risk & $\begin{array}{c}\text { Loss of quality } \\
\text { Technological risk }\end{array}$ \\
\hline
\end{tabular}

Source: own work. 
External and internal risk factors are interwoven in their operation, although it would be more correct to say that some external risks cause internal threats. Therefore, their distinction is not simple and clear.

\section{Summary and conclusions}

The use of alternative fuels for economic purposes is beneficial both for the environment and the society. However, it should be remembered that all economic activities involve various risks. While economic entities, including enterprises producing and using alternative fuels, operate in the external environment, the external factors can have a negative impact on their activities. Therefore, it is important for the management of these plants to develop a comprehensive risk management strategy based on the analysis of key risk factors. At the same time, external and internal factors shall be distinguished. In the case of the former, it is necessary to closely monitor the market situation, update legal, technological, and emission standards as well as other norms and regulations. In the case of the latter - it is necessary to monitor the basic and additional production processes and correct them on an ongoing basis. Due to the possibility of changes in the demand for manufactured products, agreements should stipulate the possibility of changes regarding the supply of raw materials and finished products.

Regardless of the type of risk and the source of its origin, all the risk factors and possible consequences for the company should be investigated. The investigations should focus not only on potential problems, but also take those types of risks that affect business partners' activities into account. Therefore, a comprehensive approach to risk management, including the development of different solutions, is recommended. Action plans for different scenarios should take the possible impact of risk factors (external and internal) on the activities of the company and its business partners into account. In addition, managers should keep track of market dynamics and be able to interpret them in the proper manner.

This publication is financed by the AGH University of Science and Technology within the subsidy for maintaining research potential.

\section{References}

BORYS, G. 1996. Credit risk management in a commercial bank (Zarzadzanie ryzykiem kredytowym w banku komercyjnym). Polish Scientific Publishers PWN, Warsaw (in Polish).

CYRANKA, M. and JURCZYK, M. 2016. Energy, economic and legal determinants for cogeneration energy recovery from municipal waste (Uwarunkowania energetyczne, ekonomiczne i prawne odzysku energii 
z odpadów komunalnych $w$ ramach układów kogeneracji). Polityka Energetyczna - Energy Policy Journal vol. 19, issue 1, pp. 99-116 (in Polish).

Directive 2008/98/EC of the European Parliament and of the Council of 19 November 2008 on waste and repealing certain Directives (22.11.2008. EN. Official Journal of the European Union)

Do H. 2014 - Risk Management of Oil Refinery, The University of Texas at Austin.

EC-DGE 2003 - Refuse derived fuel, current practice and perspectives. Final Report. European Commission - Directorate General Environment.

IWASZCZUK N. et al. 2013 - IWASZCZUK, N., ŁAMASZ, B. and OrŁOWSKA-PUZIO, J. Hedge option strategies in foreign trade (Hedgingowe strategie opcyjne w handlu zagranicznym). The AGH University of Science and Technology Press, Kraków (in Polish).

JAJUGA, K. 1998. Financial investments (Inwestycje finansowe). The Publishing House of the Wrockaw University of Economics, Wrocław (in Polish).

JAJUGA, K. 2009a. Introduction to financial investments (Wprowadzenie do inwestycji finansowych). KNF - Polish Financial Supervision Authority, CEDUR (the Education Centre for Market Participants), Warsaw (in Polish).

JAJUGA, K. 2009b. Risk management (Zarządzanie ryzykiem). Polish Scientific Publishers PWN, Warsaw (in Polish).

Hilber et al. 2007 - Hilber, T., Maier, J., ScheffKnecht, G., Agraniotis, M., Grammelis, P., KaKaRas, E., Glorius, T., Becker, U., Derichs, W., Schiffer, H.P., De Jong, M. and Torri, L. 2007. Advantages and Possibilities of Solid Recovered Fuel Co-combustion in the European Energy Sector. Journal of the Air \& Waste Management Association vol. 57, pp. 1178-1189.

Holton, G.A. 2004. Defining Risk. Financial Analysts Journal 60(6), pp. 19-25.

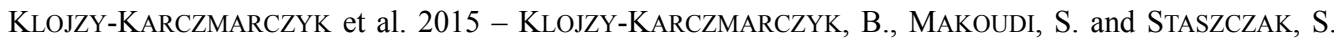
2015. Estimation of Waste Mass Directed to the Treatment in the Biological Stage of Mechanical Biological Treatment (MBT) (Szacowanie masy odpadów kierowanych do przetwarzania $w$ części biologicznej instalacji mechaniczno-biologicznego przetwarzania (MBP)). Rocznik Ochrony Środowiska vol. 17, pp. 1162-1177 (in Polish).

KLOJZY-KARCZMARCZYK, B. and STASZCZAK, J. 2017. Estimation of the mass of energy fractions in municipal waste produced in areas of different developmental character (Szacowanie masy frakcji energetycznych $w$ odpadach komunalnych wytwarzanych na obszarach o różnym charakterze zabudowy). Polityka Energetyczna - Energy Policy Journal vol. 20, iss. 2, pp. 143-154 (in Polish).

KRAWCZYK, P. and SzCZYGIEt, J. 2013. Refuse derived fuel as a fuel for CHP plant in a heating plant conditions (Analiza uwarunkowań stosowania paliwa alternatywnego do wytwarzania energii elektrycznej i ciepła $w$ warunkach przedsiębiorstwa ciepłowniczego). Rynek Energii no. 6, pp. 91-96 (in Polish).

Multimedialna encyklopedia powszechna PWN (Multimedia Encyclopedia of PWN). Edition 2003 (DVD-ROM)

PREŚ, J. 2007. Weather risk management (Zarzadzanie ryzykiem pogodowym). Warsaw: Wydawnictwo $\mathrm{CeDeWu}$ (in Polish).

Regulation of the Minister of Economy of 16 July 2015 on the acceptance of waste to landfills (Journal of Laws, 2015, item 1277).

Sobolewski et al. 2007 - Sobolewski, A., Wasielewski, R. and Stelmach, S. 2007. Utilization of solid recovered fuels in power industry (Wykorzystanie statych paliw wtórnych w energetyce). Polityka Energetyczna - Energy Policy Journal vol. 10, iss. 2, pp. 379-390 (in Polish).

SOIN, K. and COLLIER, P. 2013 - Risk and risk management in management accounting and control. Management Accounting Research 24 (2), pp. 82-87.

SZCZEPAŃSKI, J. and SZYSZKO, L. 2007. Corporate finance (Finanse przedsiębiorstwa). Warsaw: PWE (in Polish). 
The Act of 14 December 2012 on waste - uniform text (Journal of Laws of 2018, item 21).

WALENDZIEWSKI J. et al. 2017 - WALENDZIEWSKI, J., KUŁAŻYNSKI, M. and SURTMA, A. 2017. Determining the potential of waste and their types for the production of solid alternative fuels (Określenie potencjału odpadów $i$ ich rodzajów do produkcji stałych paliw alternatywnych), Wrocław, [Online] http: // www.energia.dczt.wroc.pl/files/Okre\%C5\%9Blenie\%20potencja \%C5\%82u \%20odpad\%C3\%B3w.pdf [Accessed: 2019-01-05] (in Polish).

WASIELEWSKI, R. and BAŁAZIŃSKA, M. 2018. Energy recovery from waste in the aspect of qualifications of electricity and heat as coming from renewable energy sources and to participate in the emissions trading system (Odzysk energii z odpadów w aspekcie kwalifikacji wytworzonej energii elektrycznej i ciepła jako pochodzacych z odnawialnego źródta energii oraz uczestnictwa w systemie handlu uprawnieniami do emisji gazów cieplarnianych). Polityka Energetyczna - Energy Policy Journal vol. 21, iss. 1, pp. 129-142 (in Polish).

WASIELEWSKI, R. and TORA, B. 2013. Utilization of solid recovered fuels in power industry (Zastosowanie paliw wtórnych w energetyce), [Online] http://e-czytelnia.abrys.pl/dodatek-specjalny/2013-10-709/ zeszyt-specjalny-8218/zastosowanie-paliw-wtornych-w-energetyce-16817 [Accessed: 2019-01-05] (in Polish).

Williams C.A. et al. 2002 - Williams, C.A., Smith, M.L. and YounG, P.C. 2002. Risk Management and Insurance (Zarzadzanie ryzykiem a ubezpieczenia), Warsaw: Polish Scientific Publishers PWN (in Polish).

WINKLER-DREWS, T. 2009. Price risk management (Zarządzanie ryzykiem zmiany ceny). Warsaw: PWE (in Polish).

[Online] http://www.eczabrze.fortum.pl/o-projekcie/ [Accessed: 2019-01-05].

\section{Identyfikacja czynników ryzyka związanych z wytwarzaniem i wykorzystaniem paliw alternatywnych}

\section{Streszczenie}

W artykule dokonano analizy czynników ryzyka związanego z energetycznym wykorzystaniem paliw alternatywnych produkowanych na bazie odpadów. Omówiono kwestie istoty ryzyka oraz jego wpływu na działalność gospodarczą w obszarze zagospodarowania odpadów. Następnie dokonano oceny ryzyka na przykładzie frakcji odpadów stosowanych do produkcji paliwa alternatywnego. Wskazano również korzyści, jakie przynosi społeczeństwu i środowisku przetwarzanie ich w celach energetycznych, w tym m.in.: obniżenie kosztów unieszkodliwiania odpadów; ograniczenie negatywnego wpływu na wody, glebę i powietrze; zmniejszenie ilości i wielkości składowanych odpadów; pozyskanie terenów; zmniejszenie efektu cieplarnianego; ułatwienie recyklingu pozostałych frakcji; odzysk energii elektrycznej i cieplnej; oszczędność konwencjonalnych nośników energii. 
Analiza czynników ryzyka jest przeprowadzona oddzielnie dla zakładów przetwarzających odpady na paliwa alternatywne oraz zakładów wytwarzających energię z tego rodzaju paliw. Zakłady przetwarzające odpady powinny zwrócić uwagę na ryzyko inwestycyjne, rynkowe (cenowe, stopy procentowej, walutowe), koniunkturalne, polityczno-prawne i społeczne, a także ryzyko: pogodowe, sezonowe, logistyczne, technologiczne, utraty rentowności czy upadłości. Podobne ryzyka występują też w działalności zakładów energetycznych, ponieważ funkcjonują one w tym samym otoczeniu zewnętrznym. Również ryzyka o pochodzeniu wewnętrznym mogą być podobne, jednak należy uwzględniać specyfikę działalności każdego zakładu.

W przedsiębiorstwach energetycznych szczególną uwagę należy zwrócić na zwiększenie różnego rodzaju kosztów, które może zagrozić stabilności funkcjonowania, zwłaszcza w sytuacji regulowanych cen energii. Ważne jest ryzyko związane z nieodpowiednią jakością dostarczanych i przechowywanych paliw, które może zakłócić proces technologiczny i zmniejszyć wydajność pracy zakładu. Ciepłownie i elektrociepłownie nie powinny też bagatelizować ryzyka pogodowego niekatastroficznego, którego konsekwencją jest spadek popytu na ciepło i zmniejszenie wpływów z działalności gospodarczej.

Kompleksowe podejście do ryzyka powinno uchronić przedsiębiorstwa przed ewentualnymi stratami $\mathrm{z}$ tytułu różnego rodzaju zagrożeń, płynących zarówno z otoczenia zewnętrznego, jak i tkwiących wewnątrz zakładów produkcyjnych.

SŁowA KLUCZOWE: odpady, odzysk energii, paliwa alternatywne, ryzyko, elektrociepłownie, ciepłownie, energia elektryczna i cieplna 
